\title{
IDENTIFIKASI SENYAWA KIMIA YANG MEMILIKI AKTIVITAS ANTIOKSIDAN DALAM FASE ETILASETAT ENDOKARPIUM BAWANG HUTAN
}

\author{
Wiwi Winarti ${ }^{1, *}$, Yatri Hapsari $^{2}$, Fransiska Kurniati ${ }^{1}$ \\ *email : wiwi_ffup@yahoo.co.id. \\ ${ }^{1}$ Fakultas Farmasi Universitas Pancasila, Jakarta 12640 \\ ${ }^{2}$ Puslit Bioteknologi, LIPI Cibinong 16911
}

\begin{abstract}
ABSTRAK
Berdasarkan hasil penelitian sebelumnya mengenai aktivitas antioksidan dari ekstrak metanol dalam fase etil asetat kulit kayu bawang hutan yang diperoleh secara refluks dan maserasi, diketahui bahwa nilai IC 50 dari ekstrak tersebut adalah 39,66 bpj dan 87,08 bpj. Penelitian ini bertujuan untuk mengidentifikasi senyawa kimia pada fase etilasetat dari ekstrak etanol endokarpium bawang hutan. Pada peneltian ini dilakukan pembuatan ekstrak secara maserasi kinetik menggunakan pelarut etanol 96\%, kemudian ekstrak kental etanol dipartisi dengan $n$-heksana, etil asetat dan air. Selanjutnya pada ekstrak etilasetat dilakukan penapisan fitokimia dan uji aktivitas antioksidan dengan metode peredaman radikal bebas menggunakan DPPH, kemudian difraksinasi dengan kromatografi kolom pertama. Fraksi yang diperoleh diuji aktivitas antioksidan pada konsentrasi 100 bpj. Fraksi yang mempunyai nilai \% inhibisi tertinggi difraksinasi kembali dengan kromatografi kolom kedua. Selanjutnya dilakukan pemurnian dengan KLT preparatif dan hasil KLT preparatif diidentifikasi menggunakan spektrofotometri UV-Vis, FTIR dan KG-SM. Hasil penapisan fitokimia menunjukkan ekstrak etil asetat mengandung golongan senyawa kimia flavonoid, steroid, triterpenoid, minyak atsiri dan kumarin. Uji aktivitas antioksidan terhadap ekstrak dari fraksi etil asetat diperoleh nilai $\mathrm{IC}_{50}$ sebesar 51,52 bpj. Hasil fraksinasi kromatografi kolom pertama isolat-2 dengan nilai \% inhibisi sebesar 42,86\%. Isolat terpilih dari hasil pemurnian dengan KLT preparatif adalah isolat 2.7.2 Berdasarkan analisis spektra UV-Vis, FTIR dan KG-SM diduga senyawa yang mempunyai aktivitas antioksidan adalah kolesta3,5-dien.
\end{abstract}

Kata kunci: Scorodocarpus borneensis, fase etil asetat, antioksidan.

\begin{abstract}
Based on the results of previous research in methanol extract of ethyl acetate phase of the bark forest onion by reflux and maceration, has antioxidant activity with the $\mathrm{IC}_{50}$ value of $39.66 \mathrm{ppm}$ and $87.08 \mathrm{ppm}$. This study aimed to identify chemical compounds on the ethyl acetate phase from ethanol extract of forest onion endocarpium. In this study conducted extract manufacture with kinetic maceration using ethanol 96\%, then condensed ethanol extract was partitioned with n-hexane, ethyl acetate and water. Furthermore, the ethyl acetate extract conducted phytochemical screening and antioxidant activity assay with reduction of free radicals method using DPPH, then fractionated by first column chromatography. Fractions obtained were tested antioxidant activity at a concentration of $100 \mathrm{ppm}$, the fraction that has the highest value of \% inhibition will fractionated by second column chromatography back. Further purification is done by TLC preparative
\end{abstract}


and preparative TLC results were identified using UV-Vis spectrophotometry, FTIR and GC-MS. Results of phytochemical screening showed the ethyl acetate extract containing flavonoids class of chemical compounds, steroids, triterpenoids, essential oils and coumarin. Test the antioxidant activity of the extract of ethyl acetate fraction obtained $\mathrm{IC}_{50}$ value of $51.52 \mathrm{ppm}$. The results of the first fractionation column chromatography-2 isolates with value \% inhibition of $42.86 \%$. Purified result by preparative TLC selected isolates 2.7.2 Based on the analysis of UV-Vis spectra, FTIR and GC-MS suspected of compounds that have antioxidant activity is colesta-3,5-dien.

Keywords: Scorodocarpus borneensis, ethylacetate phase, an antioxidant.

\section{PENDAHULUAN}

Antioksidan adalah suatu senyawa yang dapat menetralkan radikal bebas dan menghambat terjadinya oksidasi pada sel tubuh sehingga mengurangi terjadinya kerusakan. Secara alamiah di dalam tubuh manusia terdapat senyawa yang dapat meredam dampak negatif radikal bebas, yaitu enzim antioksidan. Namun dalam keadaan tertentu, dapat terjadi ketidakseimbangan antara jumlah radikal bebas dan antioksidan yang dapat menimbulkan stres oksidatif yang tidak diinginkan. Pada kondisi seperti ini tubuh membutuhkan asupan antioksidan dari luar yang berasal dari bahan makanan, seperti vitamin $\mathrm{E}$ dalam minyak nabati, sayur-sayuran, dan margarin; beta $(\beta)$ karoten dalam wortel; serta vitamin $\mathrm{C}$ dalam sayur-sayuran berwarna hijau atau buah-buahan $(1,2)$.

Hasil penelitian telah membuktikan manfaat mengkonsumsi tanaman berkhasiat antioksidan, seperti dapat menurunkan resiko penyakit jantung, kanker, katarak, dan penyakit degeneratif. Hal ini menjadikan antioksidan, terutama dari alam, banyak diminati di dunia saat ini (3).

Berdasarkan studi literatur tanaman bawang hutan (Scorodocarpus borneensis Becc.), banyak tumbuh di pulau Kalimantan dan Sumatera digunakan oleh masyarakat sebagai bumbu dapur karena memiliki bau yang mirip dengan bawang putih dari suku Allium karena mengandung senyawa polisulfida $(4,5)$.

Telah dilakukan penelitian pada tanaman bawang hutan oleh Rinawati (6), dalam ekstrak etil asetat kulit kayu bawang hutan yang direfluks dan di maserasi dengan metanol kemudian dipartisi dengan menggunakan etil asetat, $n$-butanol dan air, pada fase etil asetat dari proses refluks dan maserasi mempunyai aktivitas antioksidan dengan nilai IC $_{50}$ sebesar 39,66 bpj dan 87,08 bpj, mempunyai aktivitas antimikroba dengan daya hambat terhadap Staphylococcus aureus dan Escherichia coli serta menunjukkan adanya aktivitas biologi dengan metode BSLT dengan nilai $\mathrm{LC}_{50}$ sebesar 40,53 bpj dan 63,67 bpj (6). Senyawa yang terkandung dalam fase etil asetat yaitu senyawa alkaloid, flavonoid, saponin dan tanin (6). Penelitian Hartanti JN (2010), dalam ekstrak air daun bawang hutan, menunjukkan adanya aktivitas antimikroba terhadap Staphylococcus aureus dan mempunyai aktivitas biologi dengan metode BSLT dengan nilai $\mathrm{LC}_{50}$ sebesar 89,36 bpj (7). Kubota et al., telah mengisolasi dan mengidentifikasi senyawa sulfida dari ekstrak etil asetat endokarpium bawang hutan, dalam penelitian membuktikan bahwa fraksi dari ekstrak etil asetat endokarpium bawang hutan mempunyai aktivitas sebagai antimikroba $(4,5,8)$.

Berdasarkan data di atas penulis melakukan uji aktivitas antioksidan terhadap ekstrak endokarpium bawang hutan dalam fase etil asetat dari ekstrak etanol dengan metode peredaman radikal bebas menggunakan DPPH. Ekstrak etil asetat endokarpium bawang hutan difraksinasi menggunakan kromatografi kolom, selanjutnya diidentifikasi senyawa kimianya dengan spektrofotometri UV-Vis, spektrofotometri fourier-transform inframerah, kromatografi gas-spektroskopi massa (KG-SM). 


\section{METODE PENELITIAN}

\section{BAHAN}

Endokarpium bawang hutan (Scorodocarpus borneensis Becc.), etanol, aquadest, etil asetat, n-heksana, metanol, DPPH (1,1-difenil-2-pikrilhidrazil), vitamin C, ammonia $30 \%$, kloroform, asam klorida, pereaksi Dragendrorf dan Mayer, amilalkohol, ferri (III) klorida $1 \%$, pereaksi Stiasny (formaldehid 30\%-asam klorida pekat $=2: 1$ ), serbuk magnesium, natrium hidroksida $1 \mathrm{~N}$, eter, asetat anhidrat, tetes asam sulfat pekat (pereaksi Lieberman-Burchard), natrium asetat, serium sulfat, sea sand dan silika gel.

\section{ALAT}

Spektrofotometer UV-Vis (Shimadzu UV-1601), spektrofotometer fouriertransform inframerah (Shimadzu FTIR-8400S), kromatografi gas-spektroskopi massa (Agilent Technologies 5973 inert) , kolom kromatografi, timbangan analitik, lempeng kromatografi, bejana kromatografi, mikrokapiler, vial, labu tentukur, kapas, kertas saring, tangas air, l, rotavapor, inkubator, cawan penguap, lumpang dan alu, alat-alat gelas.

\section{METODE}

\section{Determinasi tanaman}

Determinasi terhadap tanaman bawang hutan, dilakukan di Pusat Penelitian Biologi-Herbarium Bogoriense LIPI, Cibinong.

\section{Pengolahan dan penyiapan bahan}

Bahan yang digunakan adalah endokarpium bawang hutan yang diperoleh dari Samarinda, Kalimantan Timur. Penyediaan bahan dengan cara membuka endokarpium buah bawang hutan kemudian dirajang dan dimaserasi.

\section{Pembuatan ekstrak fase etil asetat dari ektrak etanol 96\%}

Ditimbang sebanyak 500 gram rajangan endokarpium bawang hutan di maserasi secara kinetik sebanyak 15 kali pada suhu kamar dengan menggunakan pelarut etanol $96 \%$ masing-masing $800 \mathrm{~mL}$. Maserat yang diperoleh dikumpulkan dan disaring, diamkan lalu pekatkan dengan vakum rotavapor sehingga diperoleh ekstrak kental etanol. Ekstrak etanol dipartisi dengan pelarut $n$-heksana dan etil asetat. Kemudian ekstrak etil asetat yang didapat dipekatkan dengan rotavapor hingga diperoleh ekstrak kental etil asetat. Ekstrak etil asetat yang didapat diuji aktivitas antioksidannya dengan DPPH.

\section{Identifikasi golongan senyawa kimia}

Dilakukan identifikasi golongan senyawa kimia terhadap ekstrak kental, etil asetat endokarpium bawang hutan meliputi identifikasi golongan senyawa alkaloid, flavonoid, steroid/triterpenoid, kuinon, saponin, minyak atsiri, kumarin dan tannin.

\section{Uji aktivitas antioksidan dengan metode DPPH}

Dilakukan uji aktivitas antioksidan dengan metode DPPH sebagai berikut:

\section{Pembuatan larutan DPPH $(0,4 \mathrm{mM})$}

Ditimbang seksama lebih kurang 7,8 mg DPPH (BM 394,32) dilarutkan dengan metanol pro analisis hingga 50,0 $\mathrm{mL}$, ditempatkan dalam botol gelap.

\section{Pembuatan larutan blangko}

Dipipet $1 \mathrm{~mL}$ larutan DPPH $(0,4 \mathrm{mM})$ ke dalam labu tentukur 5,0 mL, lalu ditambahkan metanol hingga tanda, homogenkan. 


\section{Pembuatan larutan uji}

Ditimbang seksama lebih kurang $5 \mathrm{mg}$ sampel lalu dilarutkan dalaam 5,0 $\mathrm{mL}$ metanol pro analis (1000 bpj), larutan ini merupakan larutan induk. Dipipet $25 \mu \mathrm{L}, 50 \mu \mathrm{L}$, $125 \mu \mathrm{L}, 250 \mu \mathrm{L}$, dan $500 \mu \mathrm{L}$ larutan induk ke dalam labu tentukur 5,0 mL untuk mendapatkan konsentrasi sampel 5 bpj, 10 bpj, 25 bpj, 50 bpj, dan 100 bpj. Masing-masing konsentrasi ditambahkan metanol pro analisis hingga 5,0 mL, homogenkan.

\section{Pembuatan larutan vitamin $C$ sebagai kontrol positif}

Ditimbang seksama lebih kurang $5 \mathrm{mg}$ vitmin $\mathrm{C}$, larutkan dalam 5,0 $\mathrm{mL}$ metanol pro analis sehingga diperoleh konsentrasi 1000 bpj (sebagai larutan induk). Pipet $10 \mu \mathrm{L}, 20$ $\mu \mathrm{L}, 30 \mu \mathrm{L}, 40 \mu \mathrm{L}$, dan $50 \mu \mathrm{L}$ larutan induk ke dalam labu tentukur 5,0 mL untuk mendapatkan konsentrasi 2 bpj, 4 bpj, 6 bpj, 8 bpj, dan 10 bpj. Masing-masing konsentrasi ditambahkan metanol pro analisis hingga 5,0 mL, homogenkan.

\section{Uji aktivitas antioksidan}

Larutan uji dan kontrol positif dengan beberapa konsentrasi diinkubasi pada suhu $37^{\circ} \mathrm{C}$ selama 30 menit, selanjutnya diukur serapannya pada panjang gelombang maksimum $517 \mathrm{~nm}$ menggunakan spektrometer cahaya tampak.

\section{Cara perhitungan}

Rumus perhitungan peredaman radikal bebas $(\%)$ :

Peredaman radikal bebas $(\%)=($ serapan blangko - serapan sampel $) \times 100 \%$

serapan blangko

\section{Analisis ekstrak kental dengan kromatografi lapis tipis}

Ekstrak kental etil asetat dianalisis menggunakan lempeng silika gel $\mathrm{GF}_{254}$ sebagai fase diam dan menggunakan fase gerak $n$-heksana-etilasetat $(2: 1),:$ kloroform-metanol-air (5:5:1), kloroform-metanol (1:1). Bercak diamati di bawah sinar ultraviolet dengan panjang gelombang $254 \mathrm{~nm}$ dan $366 \mathrm{~nm}$ kemudian disemprot dengan pereaksi semprot (serium sulfat) dan dipanaskan sampai bercak muncul.

\section{Fraksinasi ekstrak etil asetat dengan kromatografi kolom}

Ekstrak etil asetat endokarpium bawang hutan difraksinasi menggunakan kromatografi kolom dengan fase diam silika gel dan menggunakan fase gerak yang diambil dari fase gerak kromatografi lapis tipis yang paling baik yaitu n-heksana-etil asetat secara gradien dari (2:1) sampai (1:1). Caranya sebagai berikut:

a. Gelas kolom yang telah dibersihkan dipasang tegak lurus pada statip.

b. Kemudian dibilas dengan cairan eluasi yang akan digunakan dan dikeringkan.

c. Dasar kolom diisi dengan kapas, sea sand dan silika gel. Penambahan silika gel dilakukan dengan cara mensuspensikan terlebih dahulu silika gel dengan cairan eluasi dalam gelas piala, lalu dimasukkan sedikit demi sedikit kedalam kolom dan eluen dibiarkan mengalir sampai permukaan rata. Kolom digetarkan perlahan agar silika memadat kemudian diatasnya di lapisi kertas saring.

d. Sejumlah $800 \mathrm{mg}$ ektrak kental etil asetat dihomogenkan dengan celite dan di masukkan kedalam kolom.

e. Cairan eluasi eluasi yang digunakan dituang sedikit demi sedikit kedalam kolom. Eluat dari tiap fraksi ditampung dalam vial $10 \mathrm{~mL}$ dan uapkan. 


\section{Identifikasi isolat}

\section{Spektofotometri UV-Vis}

Sejumlah isolat dilarutkan dengan pelarut yang sesuai, kemudian diukur spektrumnya pada rentang panjang gelombang 200-400 nm.

\section{Spektrofotometri faurier-transform inframerah}

Sejumlah isolat digerus dengan $\mathrm{KBr}$ hingga halus dan homogen, kemudian spektrum serapan diukur pada bilangan gelombang $4000-250 \mathrm{~cm}^{-1}$.

\section{Kromatografi gas-spektroskopi massa} KG-SM.

Sejumlah isolat dilarutkan dengan pelarut tertentu kemudian diinjeksikan pada alat

\section{HASIL PENELITIAN DAN PEMBAHASAN}

\section{Pembuatan ekstrak etanol}

Sejumlah lebih kurang 500 gram rajangan endokarpium bawang hutan dimaserasi sebanyak 15 kali pada suhu kamar dengan menggunakan pelarut etanol 96\% masingmasing $800 \mathrm{ml}$. Maserat yang diperoleh dikumpulkan dan disaring, lalu pekatkan dengan vakum rotavapor sehingga diperoleh ekstrak kental etanol 42,4 gram.

Tabel .1. Hasil ekstraksi endokarpium bawang hutan dengan pelarut etanol

\begin{tabular}{|c|c|c|}
\hline Sampel & Berat ekstrak (gram) & Rendemen (\%) \\
\hline $\begin{array}{c}500 \text { gram endokarpium } \\
\text { bawang hutan }\end{array}$ & 42,4 & 8.48 \\
\hline
\end{tabular}

\section{Partisi ekstrak etanol}

Partisi dilakukan terhadap 42,2 gram ekstrak kental etanol menggunakan nheksana-air (1:1) sebanyak 3 kali. Hasil partisi disajikan pada Tabel 2.

Tabel 2. Hasil partisi ekstrak n-heksana, etil asetat, dan air

\begin{tabular}{|c|c|c|}
\hline Ekstrak & Berat (gram) & Rendemen (\%) \\
\hline Ekstrak kental n-heksana & 16,17 & 3,23 \\
\hline Ekstrak kental etil asetat & 0,90 & 0,18 \\
\hline Ekstrak kental air & 23,02 & 4,60 \\
\hline
\end{tabular}

Partisi menggunakan pelarut yang berbeda tingkat kepolarannya, bertujuan untuk memisahkan senyawa yang bersifat non polar, semi polar, dan polar. Pelarut yang digunakan berturut-turut adalah n-heksana (non polar), etil asetat (semi polar), dan air.Rendemen tertinggi ditunjukkan oleh ekstrak air, yakni sebesar 4,60\%. Hal ini membuktikan bahwa senyawa endokarpium bawang hutan mengandung banyak senyawa polar dibandingkan senyawa non polar dan semi polar. 


\section{IDENTIFIKASI GOLONGAN SENYAWA KIMIA}

Identifikasi golongan senyawa kimia atau penapisan fitokimia dilakukan terhadap ekstrak kental $n$-heksana, ekstrak kental etil asetat dan ekstrak kental air endokarpium bawang hutan. Hasil identifikasi golongan senyawa kimia endokarpium bawang hutan disajikan pada Tabel .3.

Tabel 3. Hasil identifikasi golongan senyawa kimia endokarpium bawang hutan

\begin{tabular}{|l|l|c|c|c|c|}
\hline No & \multicolumn{1}{|c|}{$\begin{array}{c}\text { Golongan } \\
\text { senyawa kimia }\end{array}$} & $\begin{array}{c}\text { Ekstrak } \\
\text { kental n- } \\
\text { heksana }\end{array}$ & $\begin{array}{c}\text { Ekstrak } \\
\text { kental etil } \\
\text { asetat }\end{array}$ & $\begin{array}{c}\text { Ekstrak } \\
\text { kental } \\
\text { air }\end{array}$ & $\begin{array}{c}\text { Ekstrak } \\
\text { kental etanol }\end{array}$ \\
\hline 1. & Alkaloid & - & - & - & - \\
\hline 2. & Flavonoid & - & + & + & + \\
\hline 3. & Saponin & - & - & - & - \\
\hline 4. & Tanin & - & - & - & - \\
\hline 5. & $\begin{array}{l}\text { Triterpenoid/Ster } \\
\text { oid }\end{array}$ & $+/+$ & $+/+$ & $-/-$ & $+/+$ \\
\hline 6. & Kuinon & - & - & - & - \\
\hline 7. & Minyak atsiri & + & + & - & + \\
\hline 8. & Kumarin & + & + & + & + \\
\hline
\end{tabular}

Keterangan :

$+\quad$ : memberikan hasil yang positif

- $\quad$ : memberikan hasil yang negative

\section{UJI AKTIVITAS ANTIOKSIDAN DENGAN METODE DPPH}

\section{Hasil Uji DPPH terhadap ekstrak}

Hasil uji aktivitas antioksidan dengan metode DPPH terhadap ekstrak disajikan pada Tabel .4.

Tabel .4. Hasil uji aktivitas antioksidan terhadap ekstrak

\begin{tabular}{|l|l|c|c|}
\hline No & \multicolumn{1}{|c|}{ Sampel } & Konsentrasi (bpj) & \% inhibisi \\
\hline 1. & Ekstrak n-heksana & \multirow{3}{*}{100} & 43,71 \\
\cline { 1 - 1 } & Ekstrak etil asetat & & 71,15 \\
\hline 3. & Ekstrak air & & 79,21 \\
\hline
\end{tabular}

Hasil uji aktivitas antioksidan terhadap ekstrak menunjukkan bahwa aktivitas antioksidan ekstrak air > ekstrak etil asetat dengan nilai \% inhibisi sebesar 79,21\% dan $71,15 \%$. Ekstrak $n$-heksana tidak mempunyai aktivitas antioksidan karena nilai \% inhibisi dibawah $50 \%$. Kemudian dilakukan uji aktivitas antioksidan pada ekstrak etil asetat menggunakan beberapa konsentrasi dan dilanjutkan fraksinasi dengan kromatografi kolom. Hasil uji aktivitas antioksidannya disajikan pada Tabel 5. 
Tabel 5. Hasil uji aktivitas antioksidan ekstrak etil asetat endokarpium bawang hutan

\begin{tabular}{|c|c|c|c|c|}
\hline Sampel & $\begin{array}{c}\text { Konsentrasi } \\
(\mathrm{bpj})\end{array}$ & $\begin{array}{c}\text { Inhibisi } \\
(\%)\end{array}$ & IC 50 & Keterangan \\
\hline \multirow{3}{*}{$\begin{array}{c}\text { Ekstrak etil } \\
\text { asetat } \\
\text { endokarpium } \\
\text { bawang hutan }\end{array}$} & 5 & 10,78 & & \\
\cline { 2 - 3 } & 10 & 15,69 & \multirow{2}{*}{51,52} & \multirow{2}{*}{ Aktif } \\
\cline { 2 - 3 } & 25 & 40,03 & & \\
\cline { 2 - 3 } & 100 & 76,80 & & \\
\hline
\end{tabular}

Hasil uji aktivitas antioksidan menunjukkan bahwa ekstrak etil asetat endokarpium bawang hutan aktif sebagai antioksidan karena memiliki nilai $\mathrm{IC}_{50}<200$ bpj, aktivitas antioksidan dalam ekstrak etil asetat diduga karena adanya senyawa metabolit sekunder flavonoid, triterpenoid dan minyak atsiri.

\section{Hasil uji DPPH terhadap vitamin C}

Hasil uji aktivitas antioksidan dengan metode DPPH terhadap vitamin C disajikan pada Tabel 6.

Tabel.6. Hasil uji aktivitas antioksidan vitamin C

\begin{tabular}{|c|c|c|c|c|}
\hline Sampel & $\begin{array}{c}\text { Konsentrasi } \\
(\mathrm{bpj})\end{array}$ & $\begin{array}{c}\text { Inhibisi } \\
(\%)\end{array}$ & IC 50 & Keterangan \\
\hline \multirow{3}{*}{$\begin{array}{c}\text { Vitamin C } \\
\text { (kontrol } \\
\text { positif) }\end{array}$} & 2 & 12,92 & & \\
\cline { 2 - 3 } & 4 & 53,15 & \multirow{2}{*}{4,40} & \multirow{2}{*}{ Aktif } \\
\cline { 2 - 3 } & 8 & 74,96 & & \\
\cline { 2 - 3 } & 10 & 96,77 & & \\
\hline
\end{tabular}

\section{UJI AKTIVITAS ANTIOKSIDAN FRAKSI HASIL KROMATOGRAFI KOLOM PERTAMA DENGAN METODE DPPH}

Hasil uji aktivitas antioksidan dengan metode DPPH terhadap fraksi hasil kromatografi kolom pertama disajikan pada Tabel 7.

Tabel 7. Hasil uji aktivitas antioksidan fraksi hasil kromatografi kolom pertama dengan metode DPPH

\begin{tabular}{|c|c|c|c|}
\hline No. & Isolat & Konsentrasi (bpj) & \% inhibisi \\
\hline 1. & isolat- 1 & & 26,44 \\
\hline 2. & isolat -2 & \multirow{4}{*}{100} & 42,86 \\
\cline { 1 - 2 } & isolat -3 & & 47,86 \\
\hline 4. & isolat -4 & & 36,36 \\
\hline 5. & isolat-5 & & 39,15 \\
\hline
\end{tabular}


Hasil uji aktivitas antioksidan terhadap lima isolat dinyatakan tidak aktif dengan nilai \% inhibisi dibawah $50 \%$ dan menunjukkan adanya penurunan aktivitas antioksidan yang dibandingkan dengan aktivitas antioksidan pada ekstrak etil asetat, hal ini dapat disebabkan karena pada ekstrak masih banyak terkadung senyawa-senyawa yang dapat bekerja secara sinergis sehingga dapat menghasilkaan aktivitas yang tinggi, sedangkan pada hasil fraksinasi telah dilakukan pemisahan, dimana senyawa yang tadinya bekerja secara sinergis, terpisah dan aktivitas antioksidan menjadi turun. isolat-3 dan isolat-2 merupakan fraksi dengan nilai \% inhibisi tertinggi yaitu 47,86\% dan 42,86\%, dipilih isolat2 untuk dilakukan pemurnian lebih lanjut dengan kromatografi kolom kedua karena bobot isolat 2 yang paling besar diantara ke lima isolat.

\section{FRAKSINASI Isolat -2 DENGAN KROMATOGRAFI KOLOM}

Dilakukan fraksinasi isolat-2 dengan kromatografi kolom kedua. Fase gerak yang digunakan n-heksana-etil asetat 100:1 sampai 20:1. Hasil fraksinasi diperoleh 8 fraksi.

Hasil penggabungan fraksi kromatografi kolom kedua kemudian di semprot dengan larutan DPPH 0,4 mM untuk mengetahui fraksi mana yang mengandung senyawa yang dapat memberikan efek antioksidan. Hal tersebut dilakukan karena hasil fraksinasi kromatografi kolom kedua memiliki bobot yang kecil. Hasil penyemprotan dengan larutan DPPH dapat dilihat pada Gambar .1.

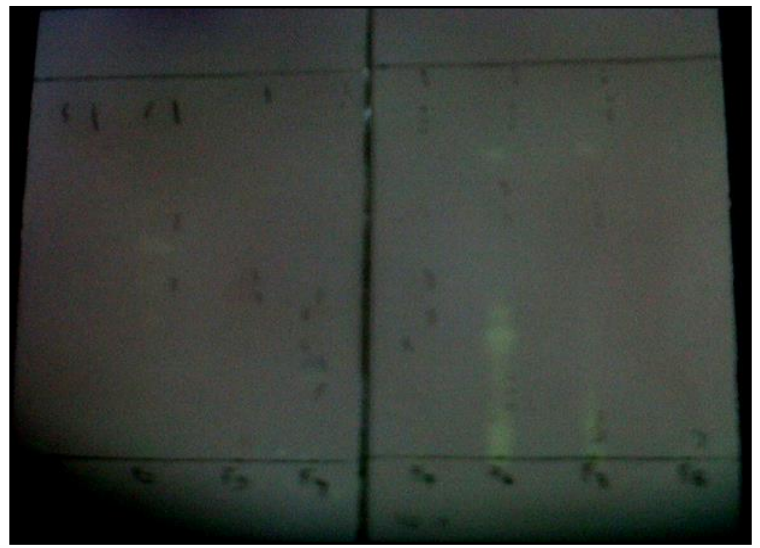

Gambar 1. Kromatogram KLT fraksi yang di semprot dengan larutan DPPH.

Hasil pemisahannya isolat 2 diperoleh 8 fraksi dan fraksi 7 merupakan fraksi yang paling baik pemisahannya pada sinar UV, memberikan warna terang/kuning setelah penyemprotan dengan larutan DPPH 0,4 mM dan memiliki bobot lebih besar dibandingkan fraksi-6, maka dipilih fraksi-7 untuk dilakukan pemurnian lebih lanjut dengan KLT preparatif.

\section{KARAKTERISASI DAN IDENTIFIKASI SENYAWA HASIL PREPARATIF}

\section{Hasil interpretasi spektra UV-Vis}

Interpretasi spektrum UV-Vis untuk isolat-2 dari fraksi-7 menunjukkan adanya serapan diatas $200 \mathrm{~nm}$ dengan puncak pada 207,5 $\mathrm{nm}$ yang memberi informasi adanya gugus kromofor yaitu gugus fungsi yang menampakkan spektrum absorbsi karakteristik pada daerah sinar UV-Vis. 


\section{Hasil interpretasi spektra Fourier-Transform inframerah}

Interpretasi spektrum Fourier-Transform inframerah untuk isolat-2 dari fraksi 7 menunjukkan bahwa ada gugus $\mathrm{C}-\mathrm{H}$ dan $\mathrm{C}=\mathrm{C}$ pada bilangan gelombang $2917.13 \mathrm{~cm}^{-1}$, $2912.31 \mathrm{~cm}^{-1}, 1674.10 \mathrm{~cm}^{-1}, 1625.88 \mathrm{~cm}^{-1}$. Hasil spektrum inframerah hasil preparatif dari fraksi-7 dapat dilihat pada Gambar 3 dan hasil analisis dapat dilihat pada Tabel 8.

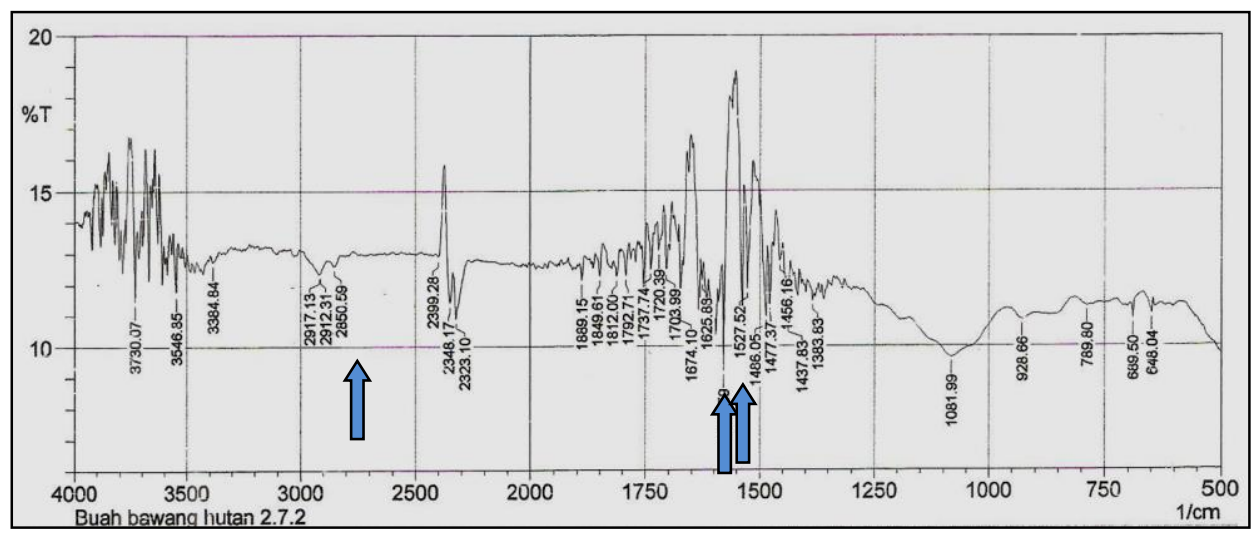

Gambar 2. Spektrum Fourier-Transform Inframerah senyawa isolat-2 dari fraksi-7 menggunakan cakram $\mathrm{KBr}$.

Tabel 8. Hasil analisis spektrum Fourier-Transform Inframerah

\begin{tabular}{|c|c|c|c|c|}
\hline No & $\begin{array}{c}\text { Bilangan } \\
\text { gelombang }\left(\mathrm{cm}^{-1}\right)\end{array}$ & $\begin{array}{c}\text { Frequency } \\
\text { Range },\left(\mathrm{cm}^{-1}\right)^{*}\end{array}$ & Ikatan* & Kandungan \\
\hline 1. & 2917.13 & $2850-2970$ & $\mathrm{C}-\mathrm{H}$ & Alkana \\
\hline 2. & $\begin{array}{l}1672.31 \\
1625.88\end{array}$ & $1610-1680$ & $\mathrm{C}=\mathrm{C}$ & Alkena \\
\hline
\end{tabular}

Ket. * : Tabel frekuensi dan panjang gelombang gugus fungsi diambil dari Skoog (28).

\section{Hasil interpretasi spektra kromatografi gas-spektroskopi massa}

Isolat-2 dari fraksi-7 yang diperoleh diidentifikasi menggunakan KG-SM. Kromatogram hasil analisa secara kromatografi gas-spektroskopi massa dapat dilihat pada Gambar 4. 


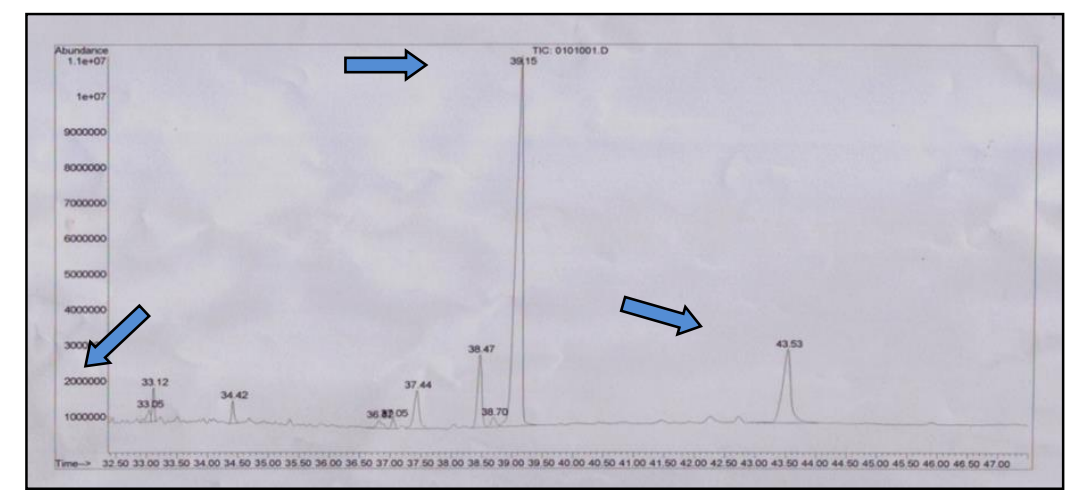

Gambar 3. kromatogram hasil analisis KG-SM isolat-2 dari fraksi-7

Pada kromatogram hasil analisa dapat dilihat bahwa isolat-2 dari fraksi-7 memiliki spektrum yang cukup baik, pada kromatogram terdeteksi beberapa puncak dengan ketinggian yang berbeda-beda. Puncak yang tinggi menunjukkan kuantitas atau kadar yang paling besar dan puncak yang rendah menunjukkan kuantitas atau kadar yang rendah pula. Dilakukan analisa terhadap kromatogram hasil KG-SM menggunakan database wiley 275.L untuk mengetahui komponen senyawa yang terdapat dalam hasil preparatif fraksi-7. Hasil analisa dapat dilihat pada Tabel 9.

Tabel 9. Hasil analisis KG-SM isolat-2 dari fraksi-7

\begin{tabular}{|c|c|c|c|}
\hline No. & Waktu retensi & Hasil analisis dengan database Wiley & \% kemiripan \\
\hline 1. & 33.12 & Asam heksanadioat & 99 \\
\hline 2. & 39.15 & Kolesta-3,5-dien & 99 \\
\hline 3. & 43.53 & Kolest- 5-en- 3-ol & 99 \\
\hline
\end{tabular}

Dari hasil yang terdeteksi pada kromatografi gas-spektroskopi massa diduga bahwa senyawa yang terdapat dalam hasil preparatif dari isolate-2 fraksi-7 dilihat dari \% kemiripan $99 \%$ yang dibandingkan dengan database Wiley 275.L dan puncak yang paling tinggi yaitu senyawa kolesta-3,5-dien.

Kolesta-3,5-dien merupakan senyawa yang mengandung inti steroid terdiri dari tiga cincin sikloheksana dan satu cincin siklopentana. Mempunyai ikatan rangkap pada C-3 dan C-5, dimana ikatan rangkap pada C-5 umumnya mencirikan suatu sterol.

Steroid dapat ditemukan pada tumbuhan tingkat tinggi dan steroid yang dimodifikasi biasanya terdapat sebagai glikosida C-3 atau ester memiliki struktur yang menyerupai struktur saponin sehingga diperkirakan mempunyai sifat yang sama seperti saponin yaitu memiliki efek antioksidan.

Spektum massa (bawah) dan struktur senyawa dari analisa dengan database willey275.L (atas) dapat dilihat dibawah ini. 


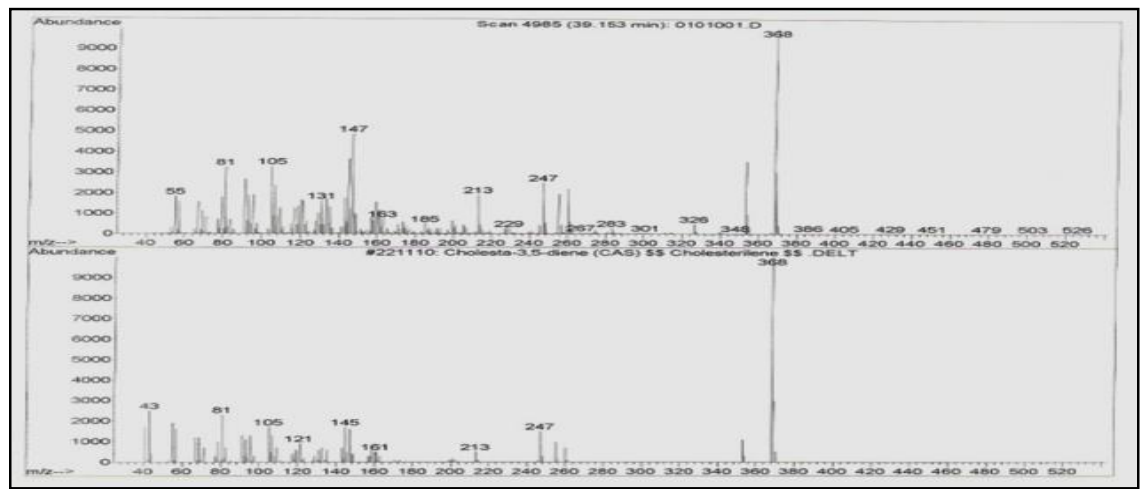

Gambar 4. Spektrum massa senyawa kolesta-3,5-dien

$\begin{array}{ll}\text { Nama senyawa } & : \text { kolesta-3,5-dien } \\ \text { Waktu retensi } & : 39,15 \\ \text { Rumus kimia } & : \mathrm{C}_{27} \mathrm{H}_{44} \\ \text { BM } & : 368,63\end{array}$

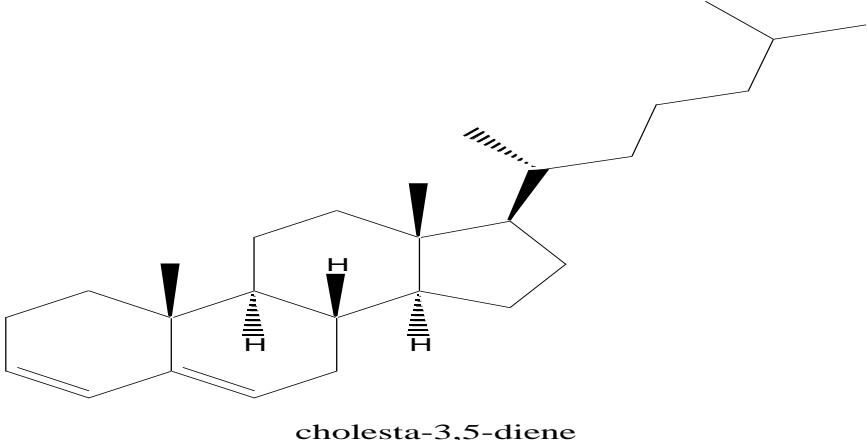

Gambar 6. Struktur senyawa kolesta-3,5-dien

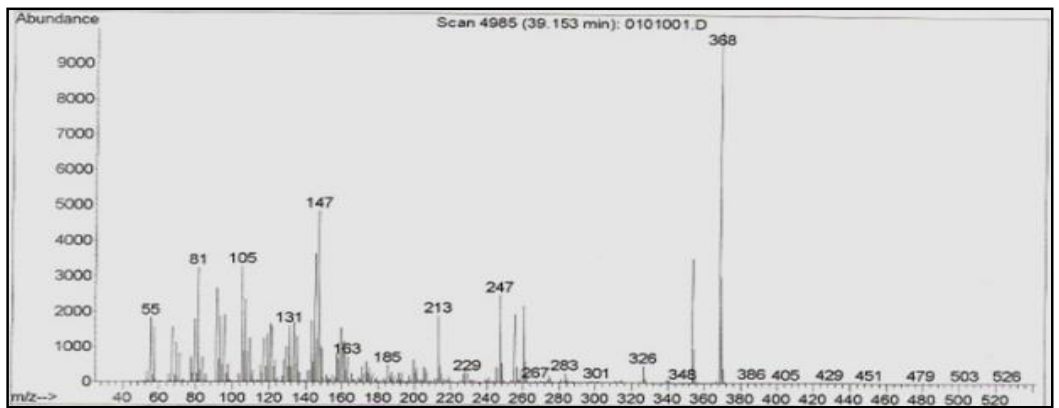

Gambar 7. Spektrum massa senyawa yang diduga kolesta-3,5-dien

Spektrum massa menunjukkan :

Memiliki puncak ion dasar dan puncak ion molekul pada $\mathrm{m} / \mathrm{z}: 368$

BM senyawa kimia $m / z: 368\left(\mathrm{M}^{+}, \mathrm{C}_{27} \mathrm{H}_{44}\right)$

Fragmentasi yang mungkin adalah : $\mathrm{m} / \mathrm{z} 247 ; 147 ; 81$

$m / z 247\left[\mathrm{M}^{+}-121\left(\mathrm{C}_{10} \mathrm{H}_{16}\right)\right]$

$m / z 147\left[\mathrm{M}^{+}-66\left(\mathrm{C}_{5} \mathrm{H}_{6}\right)\right]$

$m / z, 81\left(\mathrm{C}_{6} \mathrm{H}_{9}\right)$ 


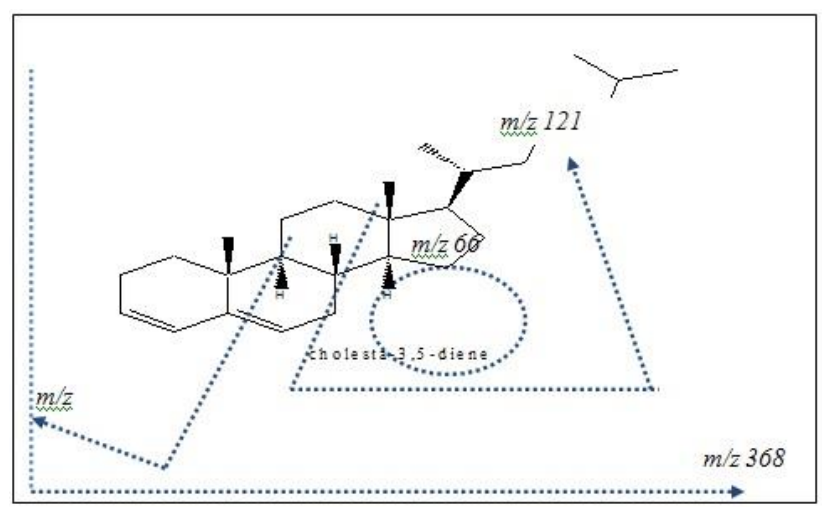

Gambar 8. Fragmentasi senyawa yang diduga kolesta-3,5-dien

\section{SIMPULAN}

Hasil penelitian menunjukkan pada identifikasi golongan senyawa kimia pada ekstrak etilasetat endokarpium bawang hutan mengandung golongan senyawa flavonoid, steroid, triterpenoid, minyak atsiri dan kumarin. Uji aktivitas antioksidan menghasilkan $\mathrm{IC}_{50} 51,52 \mathrm{bpj}$. Hasil interpetasi data spektra spektrofotometer isolat 2.7.2 menggunakan UV-Vis, menunjukkan adanya serapan diatas $200 \mathrm{~nm}$ dengan puncak pada 207,5 $\mathrm{nm}$, inframerah (IR) menunjukkan adanya gugus $\mathrm{C}-\mathrm{H}$ dan $\mathrm{C}=\mathrm{C}$, Kromatografi gas-spektroskopi massa menunjukkan adanya puncak yang dominan dengan \% kemiripan sampai $99 \%$ yang dibandingkan dengan database Wiley 275.L diduga yaitu senyawa kolesta-3.5-dien.

\section{UCAPAN TERIMAKASIH}

Pada penelitian ini penulis mengucapkan terimakasih kepada Puslit Bioteknologi, LIPI Cibinong Bogor.

\section{DAFTAR PUSTAKA}

1. Widjaja S, editor, 2008. Antioksidan: pertahanan tubuh terhadap efek oksidan dan radikal bebas. Majalah Ilmu Fakultas Kedokteran USAKTI. 1997;16(1):1659-72 dikutip dari Rachman F, Logawa ED, Hegartika H, Simanjuntak P. Aktivitas antioksidan ekstrak tunggal dan kombinasinya dari tanaman Curcuma sp. Jurnal Ilmu Kefarmasian Indonesia. Vol,6 (2):69-74.

2. Amrun H, Umiyah, 2008. Pengujian antiradikal bebas 1,1-difenil-2-pikrilhidrazil (DPPH) ekstrak buah kenitu (Chrysophyllum cainito L.) dari daerah sekitar Jember. Jurnal Obat Bahan Alam.3(2):34-9 dikutip dari Rachman F, Logawa ED, Hegartika H, Simanjuntak P. Aktivitas antioksidan ekstrak tunggal dan kombinasinya dari tanaman Curcuma sp. Jurnal Ilmu Kefarmasian Indonesia. Vol. 6 (2):69-74.

3. Yuhernita, dan Juniarti. 2011. Analisis senyawa metabolit sekunder dari ekstrak metanol daun surian yang berpotensi sebagai antioksidan. Makara, Sains ;15(1):48-52.

4. Kubota K, Matsumoto M, Ueda M, Kobayashi A, 1994. New antimicrobial coumpound from Scorodocarpus borneensis. Biosci Biotech Biochem ; 58 (2): 430431.

5. Kubota K, lim H, Kobayashi A, Sugawara F, 1998. Sulfur-containing compounds from Scorodocarpus borneensis and their antimicrobial activity. Phytochemistry. Vol.48: No. 5: p. 787-790.

6. Rinawati, 2010. Penetapan parameter faramakognosi dan uji antioksidan, antimikroba, toksisitas ekstrak etil asetat kulit batang dan daun bawang hutan 
Olacaceae (Scorodocarpus borneensis Becc.) (Skripsi). Jakarta: Fakultas Farmasi Universitas Pancasila.

7. Hartanti JN,2010. Karakterisasi farmakognosi dan uji aktivitas biologi ekstrak air daun bawang hutan (Scorodocarpus borneensis Becc.), Olacaceae (Skripsi). Jakarta: Fakultas Farmasi Universitas Pancasila.

8. Kubota K, Kobayashi A,1994. Sulfur compounds in wood garlic (Scorodocarpus borneensis Becc.) as versatile food components. Departement of Nutrition and Food Science, Ochanomizu University. Tokyo 112, Japan

9. Scorodocarpus borneensis. Diambil dari http://www.flickr.com/photos/pudin2008 /2967187836/. Diakses 12 Desember 2012.

10. Farnsworth NR, 1966. Phytochemical screening. Chicago: Departement of Pharmacognosy and Pharmacology college of Pharmacy; p. 26-62.

11. Winarsi H,2007. Antioksidan alami dan radikal bebas. Edisi V. Yogyakarta: Kanisius; h. $18,20,11-82$.

12. Skoog D, Holler FJ, Crouch S, 2007. Principles of instrumental analysis $6^{\text {th }}$ ed. Canada: Thomson Brooks/Cole;. h. 430-4.

13. Silvertein M, Webster FX, Kiemle DJ,2005. Spectrometric Identification of Organic Compounds. $7^{\text {th }}$ ed. New York: John Wiley and Sons;. h. 72-80, 215-7. 